\title{
Morphological characteristics of the southwest deep - depression East Sea region
}

\author{
Bat Van Dang 1, Chi Kim Thi Ngo ${ }^{2,}$, Binh Van Phan ${ }^{2}$, Hiep Huu \\ Nguyen ${ }^{2}$, Hau Vinh Bui ${ }^{2}$, Hien Thu Thi Bui ${ }^{2}$ \\ 1 Vietnam Union of Geological Sciences, Hanoi, Vietnam \\ ${ }^{2}$ Hanoi University of Mining and Geology, Hanoi, Vietnam
}

\section{ARTICLE INFO}

Article history:

Received 25 $5^{\text {th }}$ Mar. 2021

Revised $28^{\text {th }}$ June 2021

Accepted 28 ${ }^{\text {th }}$ July 2021

Keywords:

East Sea,

Morphological characteristics.

\section{ABSTRACT}

Morphological characteristics of the southwestern deep-depression East Sea have been defined based on the subdivision into co-origin surfaces. The results show that, the study area has 16 morphological units, including: Horizontal surface, slightly inclined surface, continental shelf accumulation, $200 \div 300$ m depth; The surface is slightly inclined and wavy

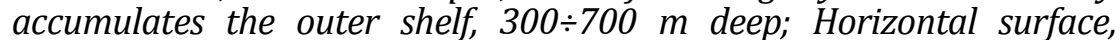
abrasive, $500 \div 700 \mathrm{~m}$ (Guyot); Abrasive horizontal surface (Guyot), depth 1,300 $\div 1,600 \mathrm{~m}$; Abrasive horizontal surface (Guyot), depth -2,000 m; The surface of the ancient volcanic crest is distributed at different depths; Young volcanic surface, 1,200 $\div 3,000$ m deep; Wavy, accumulative plain, continental rise, 1,100 $\div 1,800 \mathrm{~m}$ deep; Plain transport - accumulation plain, depth 1,100 $\div 2,300 \mathrm{~m}$; The smooth plain transports accumulates, depth 2,300 $\div 3,000 \mathrm{~m}$; The plain is divided by underground hills and mountains in the north, 2,000 $\div 2,600 \mathrm{~m}$ deep; The plain is strongly dissected of underground mountains, 1,700 $\div 2,600 \mathrm{~m}$ deep; Deep depression surface splits; Tectonic slope surface, continental slope $800 \div 1,400 \mathrm{~m}$ depth; Slope surface of the Northwestern underground mountain range 1,800 $\div 2,600 \mathrm{~m}$; Slope surface of the Southeastern underground mountain range $2000 \div 2900 \mathrm{~m}$. Based on the morphological characteristics of the study area, field investigation, and analytical results allowed us to capture the potential areas of the Fe - Mn nodule and crust, namely: morphological units such as Guyot, young volcanic surface are supposed to be the prospect of the Fe - Mn crust while the deepwater surfaces demonstrate favorable place for $\mathrm{Fe}$ - Mn nodule can produce accumulation.

Copyright (C) 2021 Hanoi University of Mining and Geology. All rights reserved.

${ }^{*}$ Corresponding author

E- mail: ngothikimchi@humg.edu.vn

DOI: 10.46326/JMES.2021.62(4).04 


\title{
Tạp chí Khoa học Kỹ thuật Mỏ - Địa chất
}

\author{
Trang điện tử: http://tapchi.humg.edu.vn
}

\section{Đặc điểm địa mạo khu vực tây nam trũng sâu Biển Đông}

\author{
Đặng Văn Bát 1, Ngô Thị Kim Chi 2, , Phan Văn Bình ${ }^{2}$, Nguyễn Hữu Hiệp ${ }^{2}$, Bùi Vinh \\ Hậu ${ }^{2}$, Bùi Thị Thu Hiền ${ }^{2}$
}

1 Tổng hội Địa chất Việt Nam, Hà Nội, Việt Nam

2 Trường Đại học Mỏ - Địa chất, Hà Nội, Việt Nam

THÔNG TIN BÀI BÁO

Quá trình:

Nhận bài 25/3/2021

Sửa xong 28/6/2021

Chap nhận đăng 28/7/2021

Tù̀ khóa:

Biển Đông,

Đặc điểm địa mạo.

\section{TÓM TẮT}

Đặc điểm địa mạo tây nam trũng sâu Biển Đông, được các tác giả làm sáng tỏ trên cơ sở phân chia ra các bề mặt đồng nguồn gốc. Kết quả nghiên cúu cho thấy, khu vực tây nam trũng sẩu Biên Đông có 16 đơn vị địa mạo, bao gồm: Bề mặt nẳm ngang, hơ nghiêng, tích tụ thềm luc địa, độ sâu $200 \div 300$ m; Bề mặt hơ nghiêng lượn sóng tích tụ thềm ngoài lục địa, độ sâu $300 \div 700$ m; Bề mặt nằm ngang, mài mòn, độ sâu $500 \div 700$ m (Gaiot); Bề mặt nằm ngang mài mòn (Gaiot), độ sâu 1.300 $1.600 \mathrm{~m}$; Bề mặt nằm ngang mài mòn (Gaiot), độ sâu -2.000 m; Bề mặt đỉnh núi lưa cổ phân bố trên các đô sâu khác nhau; Bề mặt núi lưa trẻ, độ sâu $1.200 \div 3.000$ m; Bề mặt đồng bằng lượn sóng, tích tự, chân luc địa, độ sâu $1.100 \div 1.800 \mathrm{~m}$; Bề mặt đồng bằng vận chuyển - tích tư thoải đều, độ sâu $1.100 \div 2.300$ m; Bề mặt đồng bằng thoải đều vận chuyển tích tụ, độ sâu $2.300 \div 3.000 \mathrm{~m}$; Bề mặt đồng bằng bi phân dị bởi các đồi núi ngầm phía bắc, độ sâu $2.000 \div 2.600 \mathrm{~m}$; Bề mặt đồng bằng bị chia cắt mạnh của các dãy núi ngầm, độ sâu $1.700 \div 2.600$ m; Bề mặt trũng sâu tách giãn; Bề mặt sườn dốc kiến tạo, sườn lục địa, độ sâu $800 \div 1.400$ m;

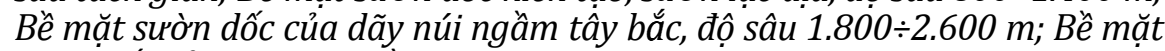
sườn dốc của dãy núi ngầm đông nam, độ sâu $2.000 \div 2.900$ m. Dựa trên các đặc điểm địa mạo kết hợp với kết quả khảo sát thực địa và phân tích mẫu của khu vực nghiên cúu, các tác giả chỉ ra nhũng khu vực có triển vong kết hach, kết vỏ Fe - Mn, cu thể là: các Gaiot, bề mặt núi lứa trẻ có triển vọng về vỏ Fe - Mn, còn trũng sâu tách giãn là có khả năng tích tụ kết hạch Fe - Mn.

C 2021 Trường Đại học Mỏ - Địa chất. Tất cả các quyền được bảo đảm.

\section{Mở đầu}

Tây nam trũng sâu Biển Đông là khu vực có cấu trúc biển rìa điển hình cho quá trình chuyển tiếp lục địa - đại dương. Khu vực nghiên cứu nằm

\footnotetext{
*Tác giả liên hệ

E - mail: ngothikimchi@humg.edu.vn DOI: 10.46326/JMES.2021.62(4).04
}

ở tọa độ từ $109015 \div 111^{045}$ kinh độ đông và từ $9^{0} 00^{\prime} \div 11^{0} 00^{\prime}$ vĩ độ bắc (Hình 1 ). Đây là khu vực nước sâu, điều kiện tiếp cận khó khăn nên có không nhiều các công trình nghiên cứu ve địa chất, đia mao va sinh khoang lien quan (Đặng Văn Bát, 2004, 2007; Ngô Thị Kim Chi, 2020; Nguyễn Hiệp, 2019; Bùi Công Quế, 2001; Phạm Như Sang, 2020; Nguyễn Thế Tiệp, 2010; Nguyễn Thị Anh Tho, 2008; Nguyễn Trọng Tín, 2010). Việc nghiên cứu đặc điểm địa mạo trong khu vực không chỉ làm 


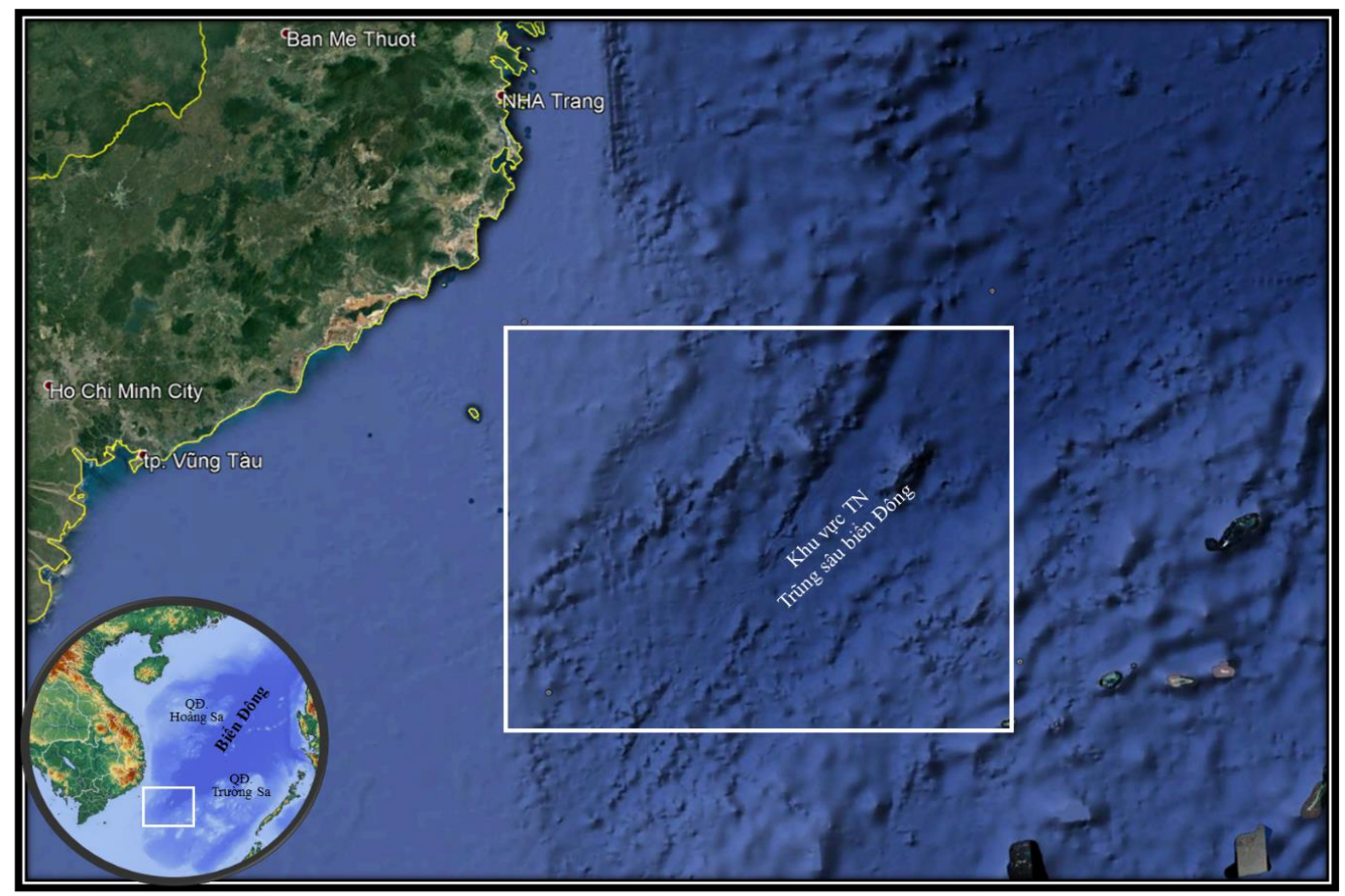

Hình 1. Sơ đồ vị trí vùng nghiên cúu.

sáng tỏ được lịch sử phát triển địa chất của khu vực nghiên cứu mà còn góp phần xây dựng các tiền đề tìm kiếm khoáng sản rắn (như Fe-Mn) (Lan Chi, 2020; Nguyễn Trọng Tín, 2010).

Khu vực nghiên cứu có đặc điểm địa hình phức tạp. Độ sâu đáy biển dao động từ $100 \mathrm{~m}$ ở phía tây đến hơn 4.000 m ở phía đông của khu vực nghiên cứu. Độ sâu của đáy biển tăng dần từ phía tây (nơi gắn với thềm lục địa) và sang phía đông (nơi gắn với đới tách giãn Biển Đông). Hình thái các đường đẳng sâu cho thấy phương phát triển chung của địa hình là phương đông bắc-tây nam, phù hợp phương cấu trúc chung của khu vực cũng như phương tách giãn Biển Đông.

\section{Cơ sở tài liệu và phương pháp nghiên cứu}

\subsection{Cơ sở tài liệu}

Để hoàn thành bài báo, nhóm tác giả đã sử dụng bản đồ đẳng sâu của các bề mặt cổ địa lý dựa trên kết quả minh giải tài liệu địa chấn 2D trong khuôn khổ đề tài cấp nhà nước KC.09.30/16-20.

\subsection{Phương pháp nghiên cứu}

Đặc điểm địa mạo tây nam trũng sâu Biển Đông, được làm sáng tỏ trên cơ sở thành lập sơ đồ địa mạo khu vực nghiên cứu. Các tác giả đã lựa chọn khuynh hướng phân tích (Geraximov, 1946) để xây dựng sơ đồ địa mạo khu vực nghiên cứu ở tỷ lệ 1:250.000, với mục đích chia ra các bề mặt đồng nguồn gốc. Trong đó, các tiêu chí để phân chia các bề mặt đó là:

- Về hình thái địa hình (thể hiện bằng những đường đẳng sâu).

- Về nguồn gốc địa hình: chia ra các bề mặt nguồn gốc nội sinh (liên quan đến hoạt động của đứt gãy, hoạt động của núi lửa) và nguồn gốc ngoại sinh (bề mặt địa hình tích tụ, bề mặt địa hình bóc mòn...).

- Về cấu trúc địa chất: các đơn vị cấu trúc lớn trong khu vực nghiên cứu là thềm lục địa, sườn lục địa, đáy biển sâu và đới tách giãn.

Các tiêu chí về trắc lượng hình thái địa hình (độ dốc địa hình, tính chia cắt địa hình, tính bất đối xứng thung lũng).

- Tiêu chí về trầm tích phủ trên bề mặt địa hình (thể hiện mối quan hệ giữa sự phân bố trầm tích trên các bề mặt địa hình).

- Tiêu chí về độ sâu đáy biển (độ sâu có tác động tới các quá trình động lực biển, tác động tới các bề mặt có nguồn gốc khác nhau).

- Tiêu chí về ranh giới địa mạo (được vẽ theo các đường đẳng sâu hoặc cắt các đường đẳng sâu phân chia các đơn vị địa mạo khác nhau). 


\section{Kết quả nghiên cứu}

\subsection{Kết quả}

Trên cơ sở thành lập sơ đồ địa mạo khu vực tây nam trũng sâu Biển Đông (Hình 2), nhóm tác giả đã xác định được 16 đơn vị địa mạo:

\subsubsection{Bề mặt nằm ngang, hơi nghiêng, tích tụ thềm}

lục địa, độ sâu $200 \div 300$ m

Bề mặt địa hình này nằm ở phía tây bắc khu vực nghiên cứu, chiều rộng lớn nhất khoảng 53 $\mathrm{km}^{2}$, kéo dài từ kinh tuyến $109010^{\prime} \div 109050^{\prime}$ với diện tích $5.389 \mathrm{~km}^{2}$. Hình dạng bề mặt mở rộng về phía bắc và thu hẹp dần ở phía nam, nằm ở độ sâu 200 m, ứng với độ sâu của thềm lục địa.

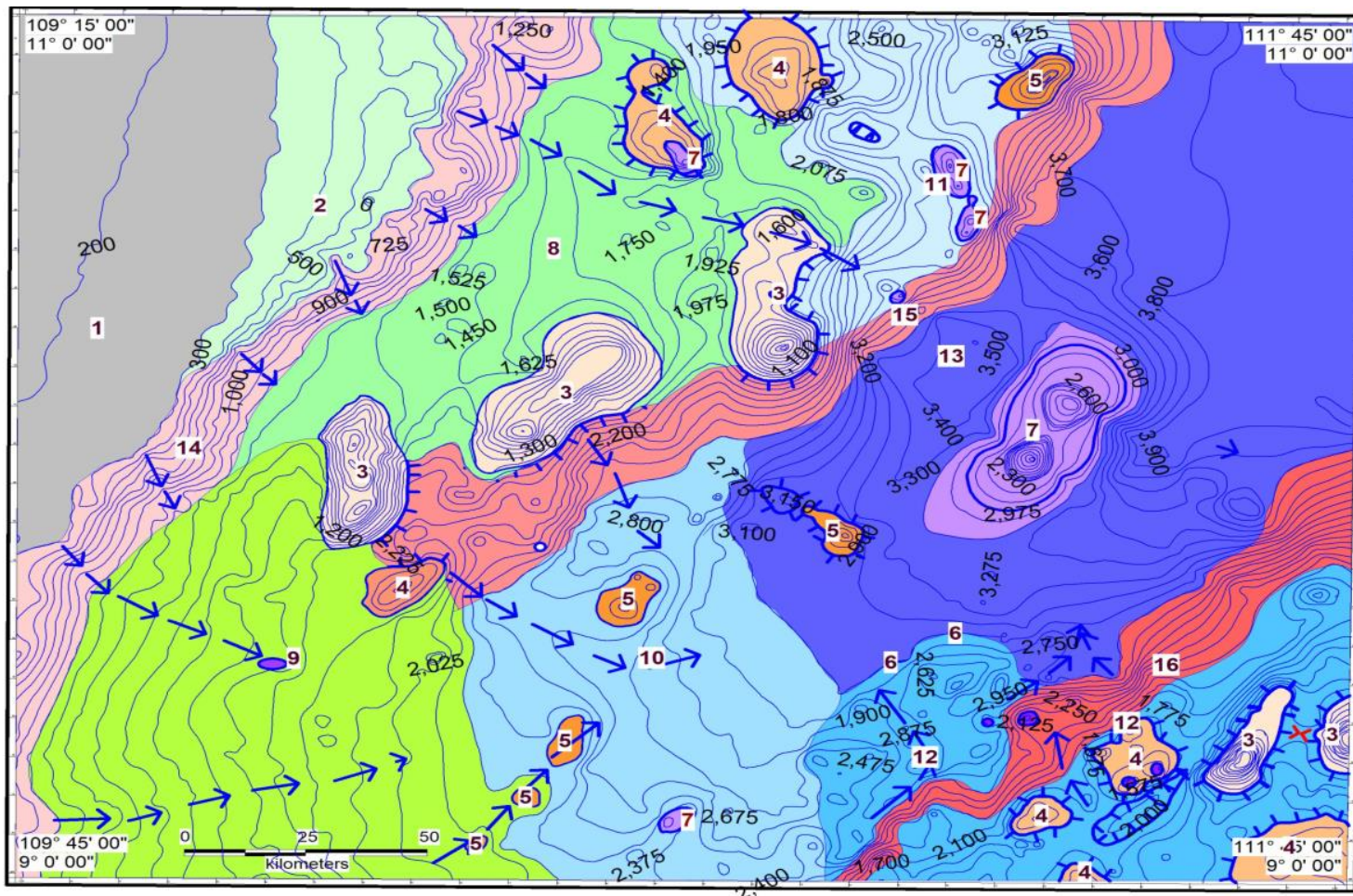

CHII DẪN

I. CÁC ĐON VỊ Cổ ĐỊA MẠO ĐỆ TƯ

I.1. ĐIA HİNH LUUC ĐIA Cố

1 Bề mật đồng bà̀ng nà̀m ngang, hơi nghiêng, tích tụ thềm lục địa. Độ sâu 200-300m

\section{I.2. ĐİA HİNH ĐÁY BIỂN}

\section{A. CÁC BỀ MặT NẰM NGANG LƯợN SÓNG}

2 Bề mật đồng bàng hơi nghiêng tích tụ thềm ngoài lục địa Độ sâu 400-700m

3 Bể mặt nà̀m ngang mài mòn (Gaiot) Độ sấu 500-700m

4 Bề mật nà̀m ngang mài mòn (Gaiot) Độ sâu 1300-1600m

5 Bề mật nà̀m ngang mài mòn (Gaiot) Độ sâu $2000 \mathrm{~m}$

Bề mặt đỉnh núi lửa cổ phân bố trên các độ sâu khác nhau Bề mật núi lửa trẻ. Độ sâu 1200-3000m B. CÁC BỀ MẠ̃T ĐỒNG BÀ̀NG

8 Bể mật đổng bằng lượn sóng, tích tụ chân lục địa Độ sâu 1100-1800m

9 Bề mặt đồng bà̀ng vận chuyển tích tụ thoải đều Độ sâu 1100-2300m

10 Bề mạat đồng bằng thoải đều, vận chuyển tích tụ Độ sấu 2300-3000m
[1] Bể mặt phân đị của các đối núi ngấm (phía bác) Độ sâu 2000-2600m

12 Bể mật chia cá́t mạnh của các núi ngấm

12 Độ sấu 1700-2600m

13 Bề mật trũng sâu tách giãn

\section{CÁC BÊ MÃT NĂM NGHIÊNG}

14 Bể mặt sườn dốc kiến tạo sườn lục địa Độ sâu 800-1400m

15 Bể mắt sườn dốc của các dãy núi ngẩm Tây Bắc Độ sâu 1800-2600m

16 Bề mặt sườn dốc của các dãy núi ngầm Đông Nam

II. CÁC KÝ HIỀU KHÁC

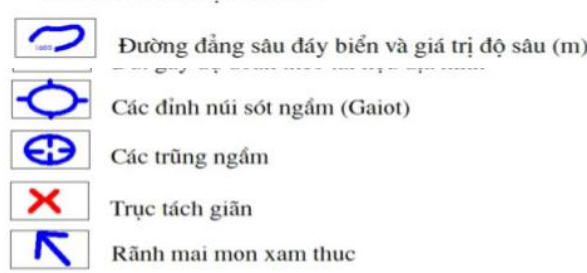

Hình 2. Sơ đồ địa mạo mạo khu vục Tây Nam trũng sâu Biển Đông. 
Bề mặt tương đối bằng phẳng, hơi nghiêng, độ dốc $<1^{0}$. Đường đẳng sâu khống chế ở đây là đường $-200 \mathrm{~m}$ và $-300 \mathrm{~m}$ (Hình 2 ). Các đường đó chạy song song, theo phương bắc-nam, khống chế cho bình đồ của thềm lục địa ở khu vực nghiên cứu (Hình 2).

\subsubsection{Bề mặt nằm ngang, hơi nghiêng lươnn sóng tích tụ thềm ngoài lục địa, độ sâu $300 \div 700 \mathrm{~m}$}

Bề mặt có hình thái nhỏ hẹp nằm ở phía bắc giữa thềm lục địa và sườn lục địa, kéo dài từ $109^{0} 50^{\prime} \div 110^{0} 30^{\prime}$ kinh độ đông, diện tích gần $2.400 \mathrm{~km}^{2}$ (Hình 2). Bề mặt kéo dài trên khoảng gần $90 \mathrm{~km}$ từ bắc xuống nam. Phía bắc bề mặt, chiều ngang có chỗ đạt tới 39 km trong khi đó phía nam thu hẹp dần, được giới hạn từ đường đẳng sâu $300 \div 700 \mathrm{~m}$. Đây là thềm lục địa ngoài của thềm lục địa Biển Đông. Các đường đẳng sâu -400 $\mathrm{m},-500 \mathrm{~m},-600 \mathrm{~m},-700 \mathrm{~m}$ chạy uốn lượn ngoằn nghèo, tạo nên tính phức tạp và lượn sóng của địa hình. Sườn phía tây của bề mặt thoải, chuyển tiếp từ từ. Ranh giới phía đông của bề mặt được chuyển tiếp từ độ sâu $-700 \mathrm{~m}$ xuống sườn lục địa. Tác động của sóng ở địa hình này không còn. Quá trình động lực ngoại sinh ở đây chủ yếu là các dòng ngầm. Các dòng ngầm được bắt đầu từ bề mặt $700 \mathrm{~m}$ đổ về phía đông xuống sườn lục địa.

\subsubsection{Bề mặt nằm ngang, mài mòn (Gaiot), độ sâu $500 \div 700 \mathrm{~m}$}

Đơn vị địa hình này phân bố ở trung tâm của vùng nghiên cứu, tại đây gặp 3 bề mặt nằm kế tiếp nhau, nổi lên giữa đáy biển (Hình 2). Bề mặt thứ nhất nằm ở phía tây, gần với sườn lục địa, có dạng dải kéo dài theo phương kinh tuyến, diện tích khoảng $558 \mathrm{~km}^{2}$. Bề mặt thứ hai có diện tích lớn nhất $\left(>900 \mathrm{~km}^{2}\right)$, nằm ở trung tâm, chạy theo phương đông bắc-tây nam. Bề mặt thứ ba, có dạng đẳng thước, nằm xa sườn lục địa nhất. Bề mặt có dạng dải, chạy theo phương kinh tuyến, diện tích bề mặt $>630 \mathrm{~km}^{2}$. Những bề mặt địa hình này tồn tại dưới đáy biển là địa hình Gaiot, một dấu hiệu địa mạo quan trọng để tìm kiếm các vỏ Fe-Mn.

\subsubsection{Bề mặt nằm ngang mài mòn (Gaiot), độ sâu} $1.300 \div 1.600 \mathrm{~m}$

Trong khu vực nghiên cứu, bề mặt nằm ngang bóc mòn ở độ sâu $1.300 \div 1.600 \mathrm{~m}$ gồm các chỏm, không liên tục nổi cao dưới đáy đại dương. Về bản chất đây cũng là những Gaiot. Ở phía bắc gặp 2
Gaiot nằm ở xung quanh tọa độ $110^{020}$ ' kinh độ đông và $10^{\circ} 50^{\prime}$ vĩ độ bắc. Hai Gaiot này có diện tích tương đương nhau, khoảng $\sim 300 \mathrm{~km}^{2}$, nối với nhau qua một yên ngựa rộng (Hình 2). Độ sâu của bề mặt nằm ngang ở $-1.300 \mathrm{~m}$ (Hình 2 ) và thấp dần xuống đến đường đẳng sâu $-1.900 \mathrm{~m}$ tạo thành những đồi ngầm dưới đáy biển. Đồi có độ dốc thoải (khoảng $2^{\circ}$ ). Gaiot phía tây nam đều bị các hoạt động núi lửa cổ xuyên cắt. Gaiot thứ ba gặp ở gần trung tâm khu vực nghiên cứu, xung quanh tọa độ 109040' kinh độ đông và 9030' vĩ độ bắc. Gaiot có diện tích nhỏ, chạy theo phương đông bắc-tây nam. Bề mặt đỉnh nằm ở độ sâu $1.600 \mathrm{~m}$ được bao quanh bởi các đường đẳng sâu $-1.700 \mathrm{~m}$ đến $-1.900 \mathrm{~m}$, tạo thành một quả đồi ngầm dưới biển. Góc đông nam của khu vực nghiên cứu gặp các Gaiot nhỏ, tạo thành một cụm liên thông với nhau bởi một yên ngựa hẹp (Hình 2). Từ yên ngựa, các dòng chảy ngầm đổ về hai hướng ngược nhau tây bắc-đông nam. Bề mặt đỉnh nằm ở độ sâu $-1.600 \mathrm{~m}$, hẹp, được khép kín bởi các đường đẳng sâu lớn hơn $-2.000 \mathrm{~m}$. Hoạt động núi lửa cổ ở khu vực này cũng thường xuyên xảy ra, xuyên cắt một trong các Gaiot đó.

\subsubsection{Bề mặt nằm ngang mài mòn (Gaiot), độ sâu $-2.000 \mathrm{~m}$}

Đơn vị địa hình này gồm 1 Gaiot nằm ở đông bắc, xung quanh tọa độ 11030' độ kinh đông và 10030 độ vĩ bắc (Hình 2) và các Gaiot nhỏ nằm rải rác ở phía nam. Gaiot nằm ở đông bắc có diện tích khoảng $50 \div 70 \mathrm{~km}^{2}$, chạy theo phương đông bắc tây nam (Hình 2). Đường đẳng sâu $-2.000 \mathrm{~m}$ tạo thành bề mặt khép kín hình tròn nhỏ. Xung quanh bề mặt này là những đường đẳng sâu $-2.000 \div$ -2.700 m bao quanh tạo thành một đồi ngầm có các sườn dốc $\left(13^{\circ}\right)$ gần như đối xứng. Có thể nói đây là những Gaiot nằm ở độ sâu lớn nhất của khu vực nghiên cứu. Trên đới tách giãn đáy đại dương cũng tồn tại một số Gaiot nhỏ chạy theo phương đông bắc - tây nam (Hình 2) với bề mặt đỉnh ở độ sâu khoảng 2.000 m làm phức tạp địa hình đáy biển.

3.1.6. Bề mặt đỉnh núi lửa cổ phân bố trên các độ sâu khác nhau

Các bề mặt đỉnh núi lửa cổ (có tuổi trước Kainozoi) phân bố rải rác ở phía đông nam khu vực nghiên cứu với diện tích không lớn (trên dưới 10 km²) (Hình 2). 


\subsubsection{Bề mặt núi lưa trẻ, độ sâu $1.200 \div 3.000 \mathrm{~m}$}

Trong khu vực nghiên cứu tồn tại ba trường núi lửa trẻ (tuổi sau Kainozoi) phủ lên bề mặt địa hình đáy biển. Các trường này có diện tích tương đối lớn được hình thành liên quan tới quá trình tách giãn Biển Đông (Hình 2). Trường thứ nhất phủ lên địa hình núi ngầm ở cánh tây bắc (Hình 2) đới tách giãn trên độ sâu $>2.000 \mathrm{~m}$ với diện tích $>60 \mathrm{~km}^{2}$. Trường thứ hai nằm ở trong đồng bằng phân bậc phát triển trên đới tách giãn (Hình 2). Trường thứ ba núi lửa trẻ thứ ba nằm ở giữa đồng bằng tách giãn (Hình 2) có diện tích lớn lên tới gần 1.320 km² (chính là núi ngầm Đình Trung).

\subsubsection{Bề mặt đồng bằng lượn sóng, tích tụ, chân lục} địa, độ sâu $1.100 \div 1.800 \mathrm{~m}$

Bề mặt nằm ở phía đông sườn lục địa, chạy theo phương đông bắc-tây nam với chiều rộng từ $22 \div 77 \mathrm{~km}$. Ranh giới phía tây của đồng bằng là một đường diềm sụt bậc từ sườn lục địa ở độ sâu $1.200 \div 1.300 \mathrm{~m}$ xuống $1.500 \mathrm{~m}$. Đường diềm này trùng với đới đứt gãy sườn đông thềm lục địa Việt Nam. Ranh giới phía đông cũng có khả năng liên quan tới đứt gãy được thể hiện bằng đường diềm sụt bậc từ hệ thống núi ngầm cánh tây bắc đới tách giãn từ độ sâu $-1.500 \mathrm{~m}$ xuống núi ngầm $-1.800 \mathrm{~m}$. Ranh giới phía đông được lấy theo đường đẳng sâu $-1.800 \mathrm{~m}$. Ở phía bắc, đồng bằng tương đối bằng phẳng, các đường đẳng sâu $-1.100 \div-1.700 \mathrm{~m}$ cách xa nhau. Về phía nam, các đường đẳng sâu $1.500 \mathrm{~m}$ và $-1.800 \mathrm{~m}$ chạy theo phương bắc - nam cách xa đều nhau trên một khoảng chiều rộng khoảng $50 \mathrm{~km}$, làm cho địa hình ở đây mang tính phân bậc (Hình 2). Trên bề mặt đồng bằng, nổi lên những Gaiot ở độ sâu -700 m và -1.600 m.

\subsubsection{Bề mặt đồng bằng vận chuyển, tích tụ thoải} đều, độ sâu $1100 \div 2300 \mathrm{~m}$

Đơn vị địa mạo nằm ở trung tâm phía nam khu vực nghiên cứu, diện tích lên đến gần 7.800 $\mathrm{km}^{2}$. Tính phân bậc của địa hình được thể hiện rất rõ ở các đường đẳng sâu từ $-1.100 \div-2.300 \mathrm{~m}$ hầu như cách đều nhau, chạy song song với nhau theo phương bắc - nam. và chuyển sang phương tây bắc - đông nam (Hình 2). Độ dốc địa hình ở đây không lớn (độ dốc $<1^{0}$ ), dốc đều. Trên bề mặt đồng bằng xuất hiện những Gaiot ở độ sâu khác nhau.

\subsubsection{Bề mặt đồng bằng thoải đều vận chuyển tích} tụ, độ sâu $2.300 \div 3.000 \mathrm{~m}$
Bề mặt phân bố ở phía nam vùng nghiên cứu, với diện tích $5.888 \mathrm{~km}^{2}$. Bề mặt có phía tây giáp với, bề mặt đồng bằng vận chuyển, tích tụ thoải đều, độ sâu $1.100 \div 2.300 \mathrm{~m}$, phía tây bắc giáp với bề mặt sườn dốc của dãy núi ngầm tây bắc, độ sâu $1.800 \div 2.600 \mathrm{~m}$, đông bắc giáp với bề mặt trũng sâu tách giãn và đông nam là bề mặt đồng bằng bị chia cắt mạnh của các dãy núi ngầm, độ sâu $1.700 \div 2.600 \mathrm{~m}$. Bề mặt đồng bằng thoải đều (độ dốc $<1^{0}$ ), các đường đồng mức chạy theo phương tây bắc-đông nam. Trên bề mặt đồng bằng có các Gaiot ở độ sâu - 2.000 m.

\subsubsection{Bề mặt đồng bằng bị phân dị bởi các đồi núi ngầm phía Bắc, độ sâu $2.000 \div 2.600 \mathrm{~m}$}

Bề mặt phân bố ở phía bắc vùng nghiên cứu, có diện tích hơn 3.040 km². Phía tây bề mặt này là bề mặt đồng bằng lượn sóng, tích tụ, chân lục địa, còn phía đông là bề mặt sườn dốc của dãy núi ngầm tây bắc. Trên mặt đồng bằng, địa hình bị phân dị mạnh, các đường đồng mức địa hình mặc dù chạy ngoằn nghèo nhưng vẫn có xu hướng theo phương kinh tuyến, tuy nhiên khoảng cách giữa các đường đồng mức khác nhau (Hình 2). Độ dốc bề mặt thay đổi mạnh, phía đông thoải (độ dốc $<1^{0}$ ), phía tây dốc mạnh hơn, có chỗ lên tới $5^{0}$. Trên bề mặt đồng bằng, tồn tại các Gaiot trên ở các độ sâu khác nhau và các núi lửa trẻ.

3.1.12. Bề mặt đồng bằng bị chia cắt mạnh của các dãy núi ngầm, độ sâu $1.700 \div 2.600 \mathrm{~m}$

Bề mặt có diện tích gần 4.600 km², nằm ở phía đông nam của vùng nghiên cứu. Bề mặt bị bề mặt sườn dốc của dãy núi ngầm đông nam chia làm hai phần. Bề mặt đồng bằng bị chia cắt rất mạnh, các đường đồng mức chạy rất phức tạp. Trên bề mặt còn xuất hiện nhiều Gaiot trên các độ sâu khác nhau và các núi lửa cổ.

\subsubsection{Bề mặt trũng sâu tách giãn}

Bề mặt này phân bố ở phía đông (Hình 2), trùng với kiến trúc hình thái của đới tách giãn đại dương chạy theo phương đông bắc-tây nam. Chúng được khống chế bởi hai đứt gãy lớn ở hai cánh. Đứt gãy cánh phía tây bắc được thể hiện là một sụt bậc từ dãy núi ngầm tây bắc xuống đồng bằng ở độ sâu $-3.000 \mathrm{~m}$. Đứt gãy cánh phía đông nam cũng là một sụt bậc từ dãy núi ngầm đông nam xuống đồng bằng cùng độ sâu $-3.000 \mathrm{~m}$. Chiều rộng của đồng bằng phân dị tích tụ này khoảng 
$38 \div 80 \mathrm{~km}$. Đây là mút tây nam cuối cùng của đới tách giãn. Cấu tạo vỏ trái đất ở đây vẫn là vỏ chuyển tiếp với lớp granit bị vát mỏng. Một góc đông bắc có vỏ đại dương, đây là một yếu tố cấu tạo vỏ quan trọng trong việc hình thành nên các loại khoáng sản rắn vỏ Fe-Mn. Bề mặt địa hình đồng bằng thấp dần từ phía tây nam lên đông bắc, từ độ sâu $-3.000 \div 4.000 \mathrm{~m}$. Tính phân dị của bề mặt địa hình thể hiện ở sự tồn tại của những Gaiot ngầm nâng cao đến độ sâu $-2.000 \mathrm{~m}$ và một số trũng sâu có hình thù khác nhau nằm ở $-3.500 \mathrm{~m}$, $-4.000 \mathrm{~m}$. Ở mút tây nam của bề mặt các đường đồng mức từ $3.000 \mathrm{~m}$ xuống $3.100 \div 3.200 \mathrm{~m}$ cách xa nhau tạo nên địa hình thoải đều (độ dốc $\sim 1^{0}$ ). Ở phía đông của đồng bằng, địa hình phân dị hơn, bị chia cắt bởi những rãnh xói ngầm. Tại trung tâm của đồng bằng tồn tại một núi lửa trẻ (núi Đình Trung) có diện tích khá lớn, cũng chạy theo phương đông bắc-tây nam. Núi lửa phủ tràn trên địa hình phân dị phức tạp.

\subsubsection{Bề mặt sườn dốc kiến tạo, sườn lục địa, độ sâu $800 \div 1.400 \mathrm{~m}$}

Đây là bề mặt sườn dốc trùng với hệ thống đứt gãy sườn đông thềm lục địa Việt Nam (Hình 2) từ độ sâu $-800 \div 1.400 \mathrm{~m}$ trên một khoảng cách không lớn $(9 \div 33 \mathrm{~km})$, làm cho độ dốc của sườn đạt tới gần $20^{\circ}$. Trên bề mặt sườn gặp các Canhon ngầm, chúng phát triển vuông góc với cấu trúc của sườn kiến tạo, tạo điều kiện để quá trình xói lở ngầm ở đây xảy ra mạnh.

\subsubsection{Bề mặt sườn dốc của dãy núi ngầm Tây Bắc, độ sâu $1.800 \div 2.600 \mathrm{~m}$}

Bề mặt này liên quan đến hai dãy núi ngầm ở cánh tây bắc đới tách giãn. Các đường đẳng sâu xít nhau, làm cho độ dốc đạt tới 150. Ở dãy núi ngầm phía tây bắc độ sâu thấp dần từ $-1.800 \div-2.600 \mathrm{~m}$ theo chiều tây bắc xuống đông nam. Ngược lại, ở dãy núi ngầm phía đông nam, độ sâu thấp dần từ $700 \div-3.000 \mathrm{~m}$ theo chiều từ đông nam lên tây bắc. Tất cả đều tạo nên các hướng dòng chảy đổ về đới tách giãn. Nhiều rãnh mài mòn-xâm thực (Canhon) được ghi nhận. Các dãy núi ngầm nằm về phía tây bắc đới tách giãn, vì vậy bề mặt sườn dốc ở đây được gọi là bề mặt sườn dốc của dãy núi ngầm tây bắc. Từ các bề mặt mài mòn Gaiot trên các độ sâu khác nhau, các sườn dốc bao quanh các bề mặt đó, sau đó có xu hướng đổ về phía đông nam, về phía trũng sâu tách giãn và về phía Bắc. Độ dốc của sườn lớn nhất bao quanh các Gaiot đạt tới trên $15^{\circ}$, trong đó dốc nhất là các sườn xung quanh Gaiot có độ sâu $700 \mathrm{~m}$ với xu thế càng tiến đến đới tách giãn độ dốc càng lớn. Ranh giới giữa các sườn dốc này với đới tách giãn là một bậc địa hình nằm trên độ sâu khoảng $3.000 \mathrm{~m}$. Bậc địa hình này trùng với đứt gãy dự đoán khống chế cánh tây bắc của đới tách giãn. Ở khu vực góc tây bắc tờ bản đồ, từ các bề mặt Gaiot ở độ sâu 2.000 $\mathrm{m}$ và các chỏm núi lửa cổ tồn tại một số bề mặt tương đối bằng phẳng ở độ sâu $2.700 \mathrm{~m}$. Về bản chất, đây là một yên ngựa lớn, chia rãnh mài mòn đổ về hai phía: phía bắc - về các trũng tích tụ nhỏ khép kín và phía đông nam - trũng sâu tách giãn.

\subsubsection{Bề mặt sườn dốc của dãy núi ngầm Đông} Nam, độ sâu $2.000 \div 2.900 \mathrm{~m}$

Phân bố ở góc đông nam, bề mặt sườn dốc di chuyển của các dãy núi ngầm được bắt đầu từ các bề mặt nằm ngang mài mòn, độ sâu $1.600 \div 1.700$ $\mathrm{m}$ (Gaiot). Từ bề mặt này các đường đẳng sâu $2.000 \div 2.900$ m đan dày xít nhau trên khoảng cách vài trăm mét, tạo thành một sườn dốc chạy theo phương đông bắc - tây nam với độ dốc của sườn khoảng $5 \div 15^{0}$. Chuyển tiếp từ Gaiot xuống sườn đổ về đồng bằng trũng sâu tách giãn theo phương từ đông nam lên tây bắc. Từ độ sâu $-2.900 \div-3.000$ $\mathrm{m}$, các đường đẳng sâu lại cách xa nhau, độ dốc địa hình $1 \div 5^{0}$, địa hình đáy biển nên thoải hơn. Trên sườn dốc cũng gặp những rãnh mài mòn để thu nước đổ về trũng sâu. Rãnh lớn nhất nằm ở phía tây đơn vị địa hình này có hình bất đối xứng xuống thu nước từ phía nam khu vực chạy theo phương tây nam - đông bắc rồi đổi hướng đông bắc - tây nam để đổ về trũng tách giãn. Trũng mài mòn này ngăn cách hai khu vực sườn có độ dốc khác nhau. Ở phía tây độ dốc nhỏ $\left(<1^{0}\right)$ hơn phía đông $\left(1 \div 5^{0}\right.$ và có chỗ $5 \div 15^{0}$ ). Phía đông nam của bề mặt Gaiot, độ dốc của địa hình các sườn đổ về phía đông nam, sườn thoải. Các vật liệu tích tụ được tập trung tại một trũng khép kín hình kéo dài trên độ sâu 2.000 m. Vật liệu trầm tích chủ yếu là bột. Trên bề mặt sườn dốc tồn tại nhiều trường bazan cổ. Tại đây cũng dự đoán một đứt gãy theo địa hình chạy theo phương đông bắc - tây nam.

\subsection{Thảo luận}

Trên cơ sở phân tích các đơn vị địa mạo và quy luật phân bố của khoáng sản sắt-magan thế giới, đồng thời xem xét tài liệu thực tế, các tác giả 
khẳng định khu vực nghiên cứu có tiềm năng khoang sản rắn $(\mathrm{Fe}-\mathrm{Mn})$.

Thứ nhất, các kết hạch $\mathrm{Fe}-\mathrm{Mn}$ thường nằm trong các vùng trũng sâuu đặc trưng là năng lượng dòng chảy yếu. Do đố, tiền đề địa mạo quan trọng nhất ở đây là bề mặt nằm ngang, trũng sâu đại dương, tích tụ những trầm tích biển thẳm, tương ứng với đơn vị địa mạo số 13 trong khu vực nghiên cứu là bề mặt trũng sâu tách giãn.

Thứ hai, khác với dạng kết hạch, vo Fe-Mn lại bám trực tiếp trên bề mặt đá gốc, cứng, bám trực tiếp trên bề mặt. Tiền đề địa mạo là các Gaiot phân bố rải rác trong khu vực nghiên cứu, tương ứng với các đơn vị địa mạo số 3,4 và 5 (các Gaiot trên các độ sâu khac nhau), thậm chí là trên bề mặt núi lửa trẻ, đơn vị địa mạo số 7.

\section{Kết luận}

Từ những kết quả nghiên cứu ở khu vực tây nam trũng sâu Biển Đông, có thể rút ra một số kết luận như sau:

1. Địa hình khu vực nước sâu tây nam Biển Đông phản ánh rõ cấu trúc địa chất của vỏ Trái đất bao gồm thềm lục địa, sườn lục địa, đáy biển sâu và đới tách giãn.

2. Các đơn vị địa mạo trong khu vực nghiên cứu gồm 16 đơn vị, cụ thể:

a. Bề mặt nằm ngang, lượn sóng: bề mặt nằm ngang, hơi nghiêng, tích tụ thềm lục địa, độ sâu $200 \div 300 \mathrm{~m}$; bề mặt nằm ngang hơi nghiêng tích tụ thềm ngoài lục địa, độ sâu $400 \div 700 \mathrm{~m}$; bề mặt nằm ngang mài mòn (gaiot), độ sâu $500 \div 700 \mathrm{~m}$; bề mặt nằm ngang mài mòn (gaiot), độ sâu $1.300 \div 16.00 \mathrm{~m}$; bề mặt nằm ngang mài mòn (gaiot), độ sâu 2.000 m; bề mặt núi lửa cổ; bề mặt núi lửa trẻ.

b. Các bề mặt đồng bằng: bề mặt đồng bằng lượn sóng tích tụ chân lục địa, độ sâu $1.100 \div 1.800$ $\mathrm{m}$; bề mặt đồng bằng vận chuyển tích tụ thoải đều, độ sâu $1.100 \div 2.300 \mathrm{~m}$; bề mặt đồng bằng thoải đều, vận chuyển tích tụ, độ sâu $2.300 \div 3.000 \mathrm{~m}$; bề mặt phân dị của các đồi núi ngầm (phía bắc), độ sâu $2.000 \div 2.600 \mathrm{~m}$; bề mặt chia cắt mạnh của các núi ngầm, độ sâu $1.700 \div 2.600 \mathrm{~m}$ và bề mặt trũng sâu tách giãn.

c. Các bề mặt nằm nghiêng: bề mặt sườn dốc kiến tạo sườn lục địa độ sâu $800 \div 1.400 \mathrm{~m}$; bề mặt sườn dốc di chuyển vật liệu của các dãy núi ngầm tây bắc; bề mặt sườn dốc di chuyển vật liệu của các dãy núi ngầm đông nam.
3. Trong khu vực nghiên cứu có những tiền đề địa mạo để tìm kiếm khoáng sản rắn. Các đơn vị địa mạo như các Gaiot, bề mặt núi lửa trẻ có tiềm năng về vỏ $\mathrm{Fe}$ - Mn, trũng sâu tách giãn là nơi có khả năng tích tụ kết hạch Fe - Mn.

\section{Lò̀i cảm ơn}

Bài báo được hoàn thành với sự hỗ trợ của đề tài cấp nhà nước KC.09.30/16-20. Các tác giả xin trân trọng cảm ơn đề tài.

\section{Đóng góp của các tác giả}

Đặng Văn Bát, Ngô Thị Kim Chi:giới thiệu chung; Đặng Văn Bát, Phan Văn Bình: cơ sở tài liệu và phương pháp nghiên cứu; Đặng Văn Bát, Ngô Thị Kim Chi: phân tích số liệu và thảo luận; Nguyễn Hữu Hiệp, Bùi Vinh Hậu, Ngô Thị Kim Chi - viết bản thảo; Đặng Văn Bát, Bùi Thị Thu Hiền: đánh giá chỉnh sửa.

\section{Tài liệu tham khảo}

Đặng Văn Bát. (cb.). (2004). Đặc điểm địa hình, địa mạo đáy biển vịnh Bắc Bộ Việt Nam tỷ lệ 1: 500.000. Đề tài Khoa học Công nghệ, Liên đoàn Địa chất biển.

Đang Van Bát. (2007). Các cau trúc hınh thái be Nam Con Sơn. Tạp chí Địa chất loạt A, 299 (3-4.2007), 25 - 30.

Ngô Thị Kim Chi, (2020). Các đơn vị kiến trúc-hình thái khu vực Tây Nam trũng sâu Biển Đông. Tuyển tập Hội nghị toàn quốc Khoa học Trái đất và Tài nguyên với phát triển bền vững năm 2020, 21-26.

Lan Chi. (2020). Ứng dụng phương pháp nghien cứu địa mạo đáy bien đe dự bao tiem nang khoang sản. Tài nguyên và Môi trường. Báo điện tử của Bộ tài nguyên và Môi trường, 299-2020.

Geraximov I. P. (1946). Kinh nghiệm lý giải địa mạo cho sơ đồ chung của cấu trúc địa chất Liên Xô. Nhưng van đe của địa ly tự nhiên. Nhà xuat bản Viện Hàn lâm Liên Xô, tập 12, Moxkva (bản Tieng Nga).

Nguyễn Hiệp. (2019). Địa chất và tài nguyên dầu khí Việt Nam. Nhà xuất bản Khoa học kỹ thuật.

Bùi Công Quế, Phùng Văn Phách. (2001). Về 
những yếu tố cấu trúc kiến tạo chính trên vùng bien Việt Nam va ke cận. Tạp chí Khoa học và Công nghệ biển, 4-2001, 1-13.

Phạm Như Sang, (2020). Đặc điểm nguồn gốc trầm tích khu vực Tây Nam biển Đông. Tạp chí Khoa học Kỹ thuật Mỏ - Địa chất, 61(5), 11-19.

Nguyễn Thị Anh Thơ, (2008). Các phương pháp nghiên cứu môi trường trầm tích Oligocene muộn ở bon trũng Nam Côn Sơn. Tạp chí Khoa học Kỹ thuật Mỏ - Địa chất, 21(01), 58 64.
Nguyễn The Tiệp. (2010). Nghiên cúu cấu trúc địa chất vùng biển nước sâu (>200 m nước) Nam Việt Nam là cơ sở khoa học để tìm kiếm Tài nguyên khoáng sản liên quan. Đe tài Khoa học Công nghệ cap nhà nước KC09 - 18/06 - 10.

Nguyễn Trọng Tín, (2010). Nghiên cúu cấu trúc địa chất và đánh giá tiềm năng dầu khí các khu vực Trường Sa và Tư Chính-Vũng Mây. Đề tài Khoa học Công nghệ cấp nhà nước $\mathrm{KC}$ 09.25/06- 10. 